greater part of this distance of 65 miles, it took the form of a crack or network of branching cracks in the soil. To the west of Mastung, where the fissuring was most marked, the ground on the west side had subsided about $2 \frac{1}{2}$ feet, though, a little farther to the south, the east side was depressed. At the point where the fissure crosses the railway from Spezand to Nushki, the lines were crumpled. The average direction of the fissure near Mastung is N. $15^{\circ} \mathrm{E}$., so that it coincides both in direction and position with the longer axis of the epicentral zone. In every place where hills crossed the line, the fissuring died out, though rock-falls were numerous. Mr. West thus concludes that the fissuring affected the alluvium only and did not penetrate the solid rock below.
The study of the earthquake has thrown little light on its origin. In the neighbourhood of Quetta, and in this part of Baluchistan only, there are several thrust-faults, in each of which the rocks on the north-west side have been forced over those on the other. One of these faults lies to the south-west of Quetta, and, though it neither coincides with the centre of the epicentral zone nor is parallel to its longer axis, a careful examination of it was made, with the result that no sign of any movement along it could be detected, though a number of rock-falls occurred in its vieinity. If, then, the earthquake was caused by a movement along a fault, it must have been connected with one that dies out before reaching the surface.
C. D.

\title{
Manufacture of Humus by the Indore Process
}

$\mathrm{T}$ HE Indore process is now fairly well known, and in the tropics it is widely used for converting all manner of plant residues into humus. A 'factory', consisting of a series of long, shallow pits, is established, and as waste organic matter becomes available it is placed in the pits in layers alternating with layers of dung, ashes, etc.; frequent watering is essential, and aeration must be promoted by maintaining a loose condition and by turning the heaps. Conditions are then favourable for the fermenting action of fungi and bacteria, and in the space of three months the material is reduced to short humus ready for application to the land. The process has been described previously, and in his lecture to the Royal Society of Arts, Sir Albert Howard dealt chiefly with the place the process, and the principles underlying it, should occupy in agriculture in the tropics and in Great Britain; the issue of the Journal of the Royal Society of Arts for November 22, 1935, includes both the lecture and the subsequent discussion, and also an appendix giving detailed directions for carrying out the process on a tea estate.

At the outset some account is given of the nature and value of humus, and the point is made that the organisms concerned in the manufacture of humus have very similar demands to those of plant roots; thus to plough in fresh organic matter tends to lower temporarily the fertility of the land, and it is urged that fermentation should occur before incorporation with the soil. A large part of the lecture deals with the improvement in fertility resulting from the adoption of the process; the system has apparently gained universal approbation in a number of tropical countries and as a means of providing manure for many different crops. In countries where much of the available dung is burnt, and where high temperatures favour rapid fermentation, it is to be expected that low humus content of the soil must often be a limiting factor in crop growth ; it is clear that where the process, with its attendant conservation of all plant residues, has been adopted, it has led to considerable increase in productivity.

Agriculturists in Great Britain will be interested most in the last two sections, which deal with the application of the principles underlying the process to conditions in Great Britain, and with the general trend of agricultural research. Here Sir Albert Howard touches on more controversial subjects. It cannot be denied that some plant residues are wasted in Great Britain, but it is difficult to believe that, if all were saved for composting, the organic manure available on the "ordinary English farm" would be doubled or trobled. It is suggested that green manure crops should not be ploughed in direct, but should first receive a dressing of farmyard manure and then be disced, so that the crop, manure and top two or three inches of soil are mixed together; to allow fermentation to occur on the surface in this manner is certainly worthy of trial, though some difficulty in subsequent ploughing might be encountered. It is difficult to agree, however, that the adoption of this method on the potato lands of Lincolnshire would prevent eel-worm attack, or that similar procedure in breaking up leys would overcome the wireworm difficulty.

Considerable stress is laid on the importance of quality in agricultural products. Quality is rather an elusive concept, but to the farmer the word will always denote those features which determine price. In regard to the tea crop, Sir Albert Howard himself uses the word in that sense, but in general his conception of it is altogether different. $\mathrm{He}$ claims that adequate organic manuring, as contrasted to the application of chemical fertilisers, produces a quality which confers immunity to all diseases (tuberculosis and foot-and-mouth disease are cited) on the animals consuming the crop; mankind, in turn, may obtain this immunity by consuming such animals or their products. It is argued that most of the ills from which we suffer are due to our N.P.K. mentality-that is, to our thinking too much in terms of the plant nutrients, nitrogen, phosphorus and potash; and it is suggested that an increase in organic manuring (not necessarily to the total exclusion of chemicals) would make it possible to dispense with the services of pathologists of all types. No evidence is offered in support of these sweeping statements and readers will probably find them difficult to accept.

The great value of the work described is, however, beyond question. Sir Albert Howard and his co-workers have undoubtedly achieved much for the tropics. His strictures on manuring in Great Britain serve to emphasise the great importance of humus (which, in fact, is scarcely ever denied), and the moment may be opportune, because mechanisation is apparently to become widespread and mechanised farming tends to foster the N.P.K. mentality. 